\title{
Personal Narrative: Caste Is My Period
}

\author{
Deepthi Sukumar
}

The Sabarimala temple in Kerala is considered by Hindus to be one of the holiest of temples in India. According to Hindu mythology, Lord Ayyappan of the Sabarimala temple is believed to be a bachelor who has taken an oath of celibacy. The temple, which sees a large annual pilgrimage of more than 20 million people, prohibits the entry of women of menstruating age (between 10 and 50 years). A Supreme Court judgment in September 2018 granted women of all age groups entry into the temple, breaking the age-old tradition. The efforts of the state government to implement the Supreme Court order was met with widespread and violent protests supported by many mainstream political parties, including a large number of women. Even women who self-identified as feminists joined in the protest against allowing menstruating women into the Sabarimala temple. A prominent female member of parliament went so far as to say, "Would you take sanitary napkins seeped in menstrual blood and walk into a friend's home? You could not. And would you think it is respectable to do the same thing when you are walking into the house of God?" (NDTV 2018). The common belief in India is that menstruating women are impure and polluting. Religion and culture have placed taboos on menstruating women in every space they occupy-at home, at work, and at places of worship. At home, a menstruating woman is prohibited from preparing food, touching pickle, curd and spice containers, cooking utensils, and even entering the kitchen and puja room (a sacred room where idols are kept and worshipped). In agricultural work, she is told not to touch the crops as they will die. These taboos are so widespread that Procter and Gamble, a U.S. multi-national company, used the campaign 'Touch the Pickle' to draw attention to menstrual taboos, targeting urban middle-class women as a marketing strategy for their 'Whisper' menstrual pads. The campaign went viral and won the Grand Prix award in Glass Lion Category at Cannes in 2015. 
Though an urban middle-class Indian woman, I did not experience these menstrual taboos or restrictions. As a Dalit, my culture is different. Dalits do not practice menstrual taboos. I was never considered or treated as polluting and impure within my own household at any time even during my periods. But 'upper caste' people including menstruating 'upper caste' women considered me to be impure and polluting even when I was not menstruating. The caste system in India is the Hindu social structure that places people by birth in a hierarchy based on ritual purity. Brahmins (priestly class) are at the top of the Hindu social order, followed by Kshatriyas (soldiers), Vysyas (traders and merchants), and Shudras (slaves and servants for the three higher castes). The Dalits are outside the caste system and considered to be polluting, impure, and untouchable by all other caste groups. To maintain the social hierarchy and inequality, the caste system has historically discriminated against the Dalits using economic and social prohibitions based on the notions of purity and pollution. Dalits were not allowed to pursue an education or own articles or economic assets relating to wealth and property. The exclusion was complete by allowing only the lowest and unclean occupations such as agricultural work, removing carcasses of dead animals, cleaning human excreta and dead bodies. In the process, Dalits became culturally different. For example, pickle-making is an 'upper caste' culture. Pickle-making allows families to preserve food and avoid waste when there is abundance. It is not seen in Dalit households, where there is only scarcity and deprivation, so my mother, grandmothers, and members of my extended family did not make pickles.

Dalit housing is spatially segregated and is considered untouchable and polluting by the dominant caste groups. When Dalits themselves and their entire environs are considered to be polluting and untouchable, becoming impure only during our menstruation just did not arise. The women in my family did agricultural labor for daily wages and food. The menstrual taboo of not touching crops did not apply to us. In general, all menstrual taboos are based on the separation of purity and pollution and therefore could not be applied to Dalit women, as we are considered impure and polluting from birth until death.

But even with this different culture, I still felt guilt and shame when I got my first period. My vagina was making an uncontrollable mess. My menstrual blood was a nuisance, and I felt I had to hide it. The first bleeding was mild. I managed to wipe and dab with pieces of cloth, which I then threw away. When my white petticoat and school uniform skirt were stained, I hid them. My mother found these clothes and asked me about them. I told her I had cut my finger while sharpening a pencil and wiped the blood on my clothes. She accepted my explanation, but she kept a lookout. Her suspicion was confirmed the first day of my next period. She told my elder sister to explain to me what to do. My sister tore up an old sari into menstrual pad-sized bits and showed me how to wrap and fold them into a pad and wear it. I had to tie a cord, a strip of cloth torn from the same old sari, around my waist then place the cloth pad over my groin between my legs. Next, I had to tie the two 
ends of the pad to the string. This was all necessary to keep the pad in place. From then on it was a 'stressful period' every month. Feelings of shame and guilt came and went periodically unexplained. Bloodstains on my dress due to ill-fitting pads made me feel ashamed and the vaginal blood gave me feelings of guilt. Nobody explained menstruation to me, so I did not understand why blood came out of my vagina. Though my family members did not explicitly tell me anything, I just felt that I must hide it.

My own menstruation made me hypersensitive to other women's periods, including my many 'upper caste' classmates in school. In my first period, I hid it and in my next, I was told very quietly how to deal with it. In contrast, when my 'upper caste' peers got their first period, their families celebrated it with rituals, new clothes, and feasting. The puberty celebrations also known as 'coming of age' or 'becoming a big girl' are to inform the community about the availability of a girl for marriage. I would wonder at this because the same family that celebrates menstruation also deems it polluting. When I went to their houses for schoolwork or other peer-related business, I would always stand or sit outside their house on the verandah, never entering their homes. Though caste and untouchability were never explained to me, I somehow knew I was different from my 'upper caste' classmates. I knew there was some 'problem' with my identity and it meant that I was not allowed to go inside 'their' houses. But as I stood on the veranda, I would not be alone. Often a woman from the house would also be there on the veranda. My classmate explained that her mother was 'outof-doors' because she was menstruating and she should not touch any article in the house except those kept aside for her 'out-of-doors' time-a water container, a plate, and a stick. I grew to feel sorry for these women when I saw them sitting outside with their plate and stick, signaling to everyone that they were menstruating. But then I would remember that these same women I pitied insisted I stand outside their home at all times, and after I left, they sprinkled 'holy' water on the place where I stood. Whether menstruating or not, Dalit women are considered impure and polluting.

In college, I went to an all-women hostel, where a new world of periods opened for me. Here we said, "I have the chums" when we had our periods. I began to wear store-bought sanitary pads-the cheaper brand without the plastic lining. Even with these pads, my days of blood-stained clothes continued. But here in the all-women hostel I stopped feeling ashamed or guilty. The college hostel was open to all. Girls from all castes and religions lived together in an equal space. We did not know or ask about each other's caste and class identities. We were aware that our different levels of self-esteem and confidence came from our different social backgrounds, but it did not go further than that. Everyone here had periods. Blood stains on dresses and disposing pads in the toilet bin were treated as matter of fact. There were no menstrual taboos. It was as if menstruation was an equalizer.

In the college hostel, we had a system to dispose of menstrual pads. I wrapped them in newspaper and put them in the trash bins. At that time, 
I did not give a thought to what happened to them after that. But now I remember that there were women who moved silently, trying to be as invisible as possible. They cleaned the toilets and took away the soiled pads. I know now that these women belonged to the same Dalit community as mine.

But when I went back from the hostel, to my home or anywhere else, things remained the same. I still felt I had to be secretive about my periods. Hiding pads and newspapers while taking them into the toilet became an art. If there were no bins inside the toilet, I did not know what to do with the pad. I felt ashamed to carry the pad around looking for a bin. Once, at home, I flushed the pad down the toilet and almost committed a murder. The drain got clogged. The manual scavenger (a Dalit who is forced into unclean occupations of cleaning latrines and sewers) was engaged. He stripped down to his loin cloth, entered through the manhole, into the blocked drain with a rope tied to his waist and held by another man standing outside. Soon there was a tug on the rope and the scavenger was pulled up, holding my pad in his hand. He came out and looked straight at me, as I was the only person there who could have used that pad. Being from my community he used my mother tongue to tell me, "I could have died today in that manhole, thank God I came out alive." Though both of us were Dalits, we were divided further and set in a social hierarchy of our occupations. I also had the added advantage of my fore-parents having converted to Christianity, which helped my father to get a college education and escape from the caste-based occupations of cleaning human excreta and menstrual waste.

By the patriarchal and caste notions of purity and pollution, all women are considered impure and untouchable during menstruation. But for Dalits, pollution and untouchability starts from birth and never ends. The 'upper caste' women become polluting and untouchable only when they are menstruating. But, even during her periods, when she herself becomes an untouchable, the 'upper caste' woman holds the Dalits, both male and female, as untouchable and polluting, periods or no periods.

At their core, the menstrual taboos are designed to maintain the systems of caste and patriarchy for the dominance of the touchable caste men. To preserve and maintain caste purity, marriages are arranged within the same caste, and women are prohibited from having marital or sexual relations with men of 'lower castes.' Menstrual taboos that deem women impure and polluting in their periods contribute to the belief system that women are inferior. This menstrual shaming of women's bodies into impure and inferior objects has allowed the male to dominate and control women and their sexuality. Women are made to carry the burden of protecting the supremacy and purity of the male and his caste with deeply ingrained cultural practices such as menstrual segregation, ritual fasting by women to protect the men, and covering the head and face in a male presence.

Most 'upper caste' feminist campaigns do not address the role of caste in menstrual taboos. As a Dalit woman, I have never been able to engage or relate to them. They do not challenge that caste and patriarchy have designed 
and planted traditions and behavior for 'upper caste' women to diligently follow and be responsible to uphold the 'purity' of their caste. Menstrual behavior and taboos are part and parcel of the caste and patriarchal design to maintain the hierarchy of caste structure by propagating and using the belief system of purity and pollution. Feminists protesting for the entry of menstruating women to the Sabarimala temple are reiterating the untouchability reference made in the Supreme Court judgment with the hashtag '\#women are not untouchable.' But they do not see untouchability and gender inequality through the lens of intersectionality. The focus is more on the inclusion of menstruating women than on the patriarchal features of the temple in the glorification and protection of male celibacy and the purification rituals therein. The discourse is silent on the problem of ritual purity being the patriarchal mechanism to maintain social inequality and the caste system. It ignores that the Dalit woman and her particular and complex problems-untouchability, caste discrimination, and oppression-are different from that of a menstruating 'upper caste' woman, yet linked to the same patriarchal and casteist scheme. The recent protests, which have raised menstruation to an unprecedented level on the gender debate, should become the entry point for addressing the role of caste and patriarchy in the complex oppression faced by Dalit women. The subject of menstrual taboos is the right context to understand gender inequality and oppression within the framework of intersectionality.

\section{REFERENCE}

NDTV. 2018. “Amid Sabarimala Row, Smriti Irani’s Sanitary Pad Comment, and a Question.” Last modified October 24, 2018. https://www.ndtv.com/india-news/ smriti-irani-will-you-take-soaked-sanitary-pads-to-friends-smriti-irani-on-sabarimala-1936170. 
Open Access This chapter is licensed under the terms of the Creative Commons Attribution 4.0 International License (http://creativecommons.org/licenses/ by $/ 4.0 /)$, which permits use, sharing, adaptation, distribution and reproduction in any medium or format, as long as you give appropriate credit to the original author(s) and the source, provide a link to the Creative Commons license and indicate if changes were made.

The images or other third party material in this chapter are included in the chapter's Creative Commons license, unless indicated otherwise in a credit line to the material. If material is not included in the chapter's Creative Commons license and your intended use is not permitted by statutory regulation or exceeds the permitted use, you will need to obtain permission directly from the copyright holder. 